\title{
Prevalence and Correlates of Physical Inactivity during Leisure-Time and Commuting among Beneficiaries of Government Welfare Assistance in Poland
}

\author{
Dorota Kaleta $^{1, *}$, Sylwia Kalucka ${ }^{1}$, Franciszek Szatko ${ }^{1}$ and Teresa Makowiec-Dąbrowska ${ }^{2}$ \\ 1 Department of Hygiene and Epidemiology, Medical University of Lodz, 90-647 Lodz, Poland; \\ sylwia.kalucka@umed.lodz.pl (S.K.); franciszek.szatko@umed.lodz.pl (F.S.) \\ 2 Department of Work Physiology and Ergonomics, Nofer Institute of Occupational Medicine, 91-348 Lodz, \\ Poland; tmd@imp.lodz.pl \\ * Correspondence: dkaleta@op.pl; Tel.: +48-426-781-688
}

Received: 30 August 2017; Accepted: 19 September 2017; Published: 26 September 2017

\begin{abstract}
Physical activity (PA) has well-documented health benefits helping to prevent development of non-communicable diseases. The aim of the study was to examine the prevalence and factors associated with physical inactivity during leisure-time (LTPA) and commuting (CPA) among adult social assistance beneficiaries in Piotrkowski district. The studied sample consisted of 1817 respondents. Over $73 \%$ of the study population did not meet the recommended levels of LTPA. Fifty two \% of the respondents had none leisure-time physical activity and $21.5 \%$ exercised occasionally. Main reasons for not taking up LTPA included: high general physical activity (36.4\%), lack of time $(28.1 \%)$, no willingness to exercise $(25.4 \%)$. Close to $82 \%$ of the surveyed population did not practice commuting physical activity (CPA). The men had higher risk for inactivity during LTPA compared to the women ( $\mathrm{OR}=1.35 ; 95 \% \mathrm{CI}$ : 1.11-1.65; $p \leq 0.05)$. Higher odds of CPA inactivity were associated with unemployment, moderate and heavy drinking and having a number of health problems. The prevalence of physical inactivity among the social assistance recipients is much higher than it is in the general population. Promotion of an active lifestyle should take into consideration substantial differences between the general population and disadvantaged individuals and their various needs.
\end{abstract}

Keywords: physical activity; commuting; social; walking; bicycling; leisure; correlates; disadvantaged groups; low socio-economic status population

\section{Introduction}

Physical activity (PA) is a low-cost, non-pharmacological, but well-documented and the most effective way to maintain good health, self-rated health and prevent development of non-communicable diseases (e.g., cardiovascular diseases) [1]. Regular physical activity is associated with a number of health benefits, including: a reduced risk of premature mortality (mainly because of cardiovascular diseases), obesity, diabetes [2,3] as well as some kinds of cancer (e.g., breast cancer [4,5], colorectal cancer [6]) and depression [7]. Despite the well-known benefits of physical activity, there is a worldwide trend towards lesser and lesser total daily physical activity. Nowadays, it is estimated that globally, approximately, one third of adult population do not achieve the recommended levels of physical activity [8]. In Europe, the studies reveal that more than one third of adults are insufficiently active [9]. Recent data from the European Union countries (EU) indicate that six in every 10 people above 15 years of age never or seldom exercise or play a sport, and more than one half of them never or seldom engage in any other kinds of physical activity, such as: cycling, dancing or gardening [8]. 
At the same time, a high proportion of adults in Europe spend more than four hours a day sitting, which could be a contributing factor to a sedentary lifestyle [9]. The level of physical activity is also not satisfactory among Polish population [10]. In 2011 less than one half of adult working population had PA lasting at least $30 \mathrm{~min}$ on most days of a week and less than one third of the studying population commuted actively [11]. As a consequence, physical inactivity has become a leading risk factor for ill health. Physical inactivity is estimated as the fourth leading risk factor for global mortality, which is responsible for about 3.2 million deaths yearly [12]. In the WHO European Region about 1 million deaths (about 10\% of the total) and 8.3 million disability-adjusted life years lost per year are attributable to physical inactivity. Moreover, physical inactivity is estimated to cause $5 \%$ of the burden of coronary heart disease, $7 \%$ of type 2 diabetes, $9 \%$ of breast cancer and $10 \%$ of colon cancer [3]. Therefore, the European Union, the United States Department of Health and Human Services and the World Health Organization promote a healthy active lifestyle and recommend undertaking regular physical activity [13-15]. It has been observed that the prevalence and correlates of LTPA depend on a country and on an ethnic group, and this aspect has been studied most widely in Western countries, mostly examining urban populations [16]. Research on the correlates of physical activity among disadvantaged subgroups and populations is relatively scarce, especially in rural Poland.

In order to develop effective interventions and to control a physically inactive population, we need to find out and understand which factors influence people's decision to practice physical activity or not to do it. There are many determinants associated with physically inactive adults. Physical activity constitutes a combination of behaviors, which are determined by interaction of a large number of factors. These determinants include: a social, personal, environmental setting and a kind of physical activity. All these factors are dependent on an individual group (e.g., disadvantaged), ethnic subgroup and whole populations. For instance, a study conducted in 28 European countries, has shown that a low physical activity was correlated with: being unemployed, being a student, being a retired person and having a higher household income [17]. Most studies examining the impact that a residential location has on physical activity, have shown that the recommended physical activity guidelines are less likely to be met by residents of rural areas when compared to the residents of urban ones. Differences between residents of urban and rural areas have been highlighted by several studies. Inter alia, studies by Parks, Housemann, and Brownson have reported significant differences in the importance of venues to exercise with respect to physical activity behavior [18]. Namely, urban adults found it important to have access to parks, walking trails and exercise equipment. At the very same time it was access to neighborhood streets for activity and an indoor gym that were more important for rural adults.

Moreover, comparison between the rural environment and urban one, reveals different barriers to being physically active. According to the existing data, the most important barriers for rural women to do physical exercises are: caregiving duties and the remoteness, while in the case of urban women it is lack of time [19]. Rural women do not pay attention to pavements, streetlights, high crime, access to park or facilities in their area, as opposed to women who live in the city, where these are essential reasons for continuing PA [20]. Rural residents with a lower income, low level of education, greater body mass indices are less likely to meet physical activity recommendations than residents of urban areas [18-20]. On the other hand, some studies have noted that the prevalence and correlates of different types of physical activity differ across countries, ethnic groups, cultures and genders. In economically advanced and rapidly developing countries people spend more and more time on occupational activities at the expense of leisure time, which they should spend relaxing and doing physical activity. Long working hours (mainly sitting at work) and psycho-social work demands have a negative impact on leisure time physical activity (LTPA). People with a low level of occupational physical activity (OPA) are at risk of inactivity and have developed obesogenic behaviors (e.g., lack of physical activity, sedentariness on the job) [21]. Therefore, prevention of development of non-communicable diseases cannot be limited only to LTPA, but it should also include another type of physical activity, i.e., commuting (CPA-walking or biking to work). Some participants may experience 
barriers towards regular commuting physical activity. One of them is associated with the presence of vehicles for both sexes in a household [22]. In addition, even high educational and occupational status urban women who in general exercise more, have negative predictors of total and leisure-related PA because of major barriers to being physically active, such as: weather, tradition, lack of facilities and time [23]. Sometimes, because of so diverse socio-economic factors (e.g., religion, tradition, customs) it is difficult to recommend one particular type of PA. Even though all positive effects of PA are well known, it is very difficult to maintain a moderate to vigorous level of physical activity in the general population for a long time. It is even more problematic in the case of disadvantaged people, who on a daily basis have numerous difficulties (not only economic) [24]. Most studies indicate that PA during leisure-time is more common and frequent in high socio-economic groups when compared to low socio-economic ones. However, these socio-economic differences are not observed in transport PA in European adults [25] and some Asia-Pacific countries [26]. Generally, the prevalence of physical inactivity in some countries is associated with low education [27-29], elderly age [28], low socio-economic status (SES) [28] and more health problems [10,29]. But there are some countries where for example age is not a problem and a regular physical activity increases with it and people live the longest in the world $[26,30]$. Total physical inactivity is negatively correlated with unfavorable neighborhood indicating that unfavorable neighborhood-social culture and religion conditions [29], lack of support groups - discourages PA [31,32]. On the other hand, in some populations good access to exercise facilities and a friendly, safe neighborhood environment can determine a specific type of physical activity and significantly increase the level of each physical activity in all ages (even elderly or disadvantaged) [30,33]. Different populations have diverse needs and challenges with regard to the promotion of physical activity. This needs to be taken into account by policy-makers. Studies on many aspects of physical activity have been published but detailed data on the prevalence of physical activity and commuting PA among disadvantaged people are scarce. Disadvantaged groups remain the most heterogeneous group with differentiated needs and problems (health, social, functional status and other). Furthermore, little is known about the factors that may strongly influence physical inactivity in the socially disadvantaged people. Knowledge is needed for present and future generations, because a sedentary lifestyle in parents is a negative pattern for their children. Children, whose parents were physically inactive, had $147 \%$ higher odds of copying their parents' behavior than children whose both parents were physically active [34]. Therefore, it is important to understand the disadvantaged group and the correlates of PA participation. Up till now, no data have been published that would present both types of physical activity (LTPA and CPA) in disadvantaged groups in Poland.

The primary purpose of this study was to examine the prevalence of physical inactivity during leisure-time (LTPA) and commuting physical activity (CPA) among adult social assistance beneficiaries, and to analyze factors associated with the lack of physical activity (in both domains) in the study population.

\section{Materials and Methods}

\subsection{Characteristics of the Examined Region}

Piotrkowski district (Piotrków Trybnalski, Poland) was selected to perform studies and implement interventions among beneficiaries of government welfare assistance. Piotrkowski district is situated in the center of Poland and belongs to Lodzkie voivodeship (Lodz Province, Poland). The district is located on the area of upland. Flatland prevails, which favors agriculture and animal breeding. One fourth of the district is forest, which constitutes the most serious component of natural resources in this region. Piotrkowski district is rich in sand and gravel deposits that are used mainly in the construction industry. According to the data of 31 December 2012 on the premises of Piotrkowski district there were in total 5199 administrative entities (182 in public sector and 5017 in the private one). Based on the REGON register (National Official Register of Entities of the National Economy) during this period, the prevailing entities functioned in the field of: wholesale and retail, car repair (1551), construction 
(727), agriculture, forestry, hunting and fishing (307). In terms of surface, small and medium farms (up to 20 ha of arable land) dominate, belonging to the mechanized category to an average or elementary extent. Agricultural lands belong mainly to individual farmers. On the premises of the district farms specialized in the production of different grains prevail. Most seldom business existing on the premises of Piotrkowski is related to the real estate industry, culture, entertainment and recreation $(92)[35,36]$.

Piotrkowski district was selected based on the analysis written by the United Nations Development Program (UNDP) because of a few reasons. Firstly, in 2013 in Piotrkowski district there were about $9 \%$ of residents who required support of social assistance institutions [35]. Another reason was the fact that this region was identified as the 11th among all 314 rural districts with the lowest indicators of social development in Poland [36]. The indicators of social development were based on the Local Human Development Index (LHDI). The LHDI index including three indicators: Health Index, Education Index and Welfare Index amounts to 25.97, with Health Index (HI) equal 26.50. However, in Lodzkie vioivodeship the LHDI index amounted to 39.28 with HI-31.48, respectively [37]. The poverty threshold, as adopted by the social assistance institutions, was determined as the income lower than specific poverty lines as identified in the Social Assistance Act [35]. This approach to the poverty line is binding upon all the district level social assistance institutions, where within the group of 11,867 social assistance beneficiaries there were 4336 families [35]. The further reason was, that Piotrkowski district is one of 156 Polish districts where overall mortality rate is the highest and mortality arises from the top five causes of death [38,39].

Taking this into consideration Polish government along with the Norwegian Directorate of Health Affairs have implemented Project PL-13 "Reducing social inequalities in health" [38]. This project was funded by the Polish state and the Norwegian Financial Mechanism 2009-2014 (www.eeagrants.org). During this period, 156 Polish districts with the highest overall mortality rates took part in it. It aimed mainly at reduction of inequalities in health among the residents of Piotkowski district through an initiative known as "Your heart is your life". There were a number of actions (e.g., health promotion) targeting the socio-economically disadvantaged population. In this study, the socio-economically disadvantaged people are defined as individuals who have minimum income of no more than 634 PLN (148 Euro) for a single person monthly, and 514 PLN (120 Euro) for a family member monthly [36]. At the same time average income was 1340 PLN (313 Euro) for a single person monthly. In Poland income of an individual citizen is assessed based on PIT (individual income tax) that is obligatorily submitted each year to the tax office. During the study income of the participants was verified based on the available financial sources (PIT). There was no way to check if the partcipants have other, additional sources of income. Another form of assessing the low level of life was a question addressed to the participants and included in the questionnaire-subjective assessmen of monthly income.

\subsection{Characteristics of the Study Sample}

According to the Central Statistical Office, in 2013 there were 91,618 residents (including 45,223 men and 46,395 women) living on the premises of Piotrkowski district [35]. More than $90 \%$ of those residents lived in rural areas. Then there was a group of 11,867 social assistance beneficiaries, including 3636 adult residents aged $18-59$ years.

A cross-sectional study was carried out among the residents of Piotrkowski district who received aid from the local social assistance organizations. The list of the recipients was provided by the local government. The study covered all the individuals registered in the local government welfare assistance institutions. The socially disadvantaged people agreed in writing to take part in the study and they fulfilled the inclusion criteria. The study was approved by the Bioethics Committee of the Medical University of Lodz in Poland (No. is RNN/243/15/KE). Data sources were derived from representative population surveys of individuals aged between 18 and 59 years (both males and females) who benefited from the local social assistance. The surveys were conducted between October 2014 and November 2014 among those beneficiaries who at the time of the study resided in 
Piotrkowski district. Data collected from the participants concerned the month preceding the study. At that time the climate was moderate and it was possible to be physically active.

\subsection{Characteristics of the Participant's Survey}

The study was carried out by the use of a questionnaire, which was adopted from the Multi-Center National Population Health Examination Survey (WOBASZ) [38]. In the questionnaire closed questions prevailed. They gave the participants a choice of answers only within a particular category. Qualitative data prevailed in the questionnaire and that was its another feature. Only singular data were quantitative (e.g., BMI, number of smoked cigarettes). The questionnaire was completed by qualified interviewers at the respondents' places of residence during face-to-face interviews. Actual performance of the surveys was preceded by several training meetings for all the survey staff, and then verified by a pre-test. Data collection was coordinated and supervised by a principal investigator, study coordinator and two field supervisors.

The questions included in the survey form covered a number of important issues, which were determined by four purposes of the study.

\subsubsection{Basic Demographic Data}

Firstly, basic demographic data have been collected. They included: gender (female and male), age (in years, divided into several groups), education (primary, vocational, secondary, high) and employment status (permanent job, temporary job, disabled or retired, student, unemployed). The questionnaire also included questions on the subjective assessment of: monthly income, living conditions, cohabitation with somebody and having children. Monthly income was assessed according to five categories: sufficient to cover all living needs plus he/she may save a certain amount, sufficient to cover all living needs, sufficient to cover basic needs only, not sufficient to cover even basic needs, declined, don't know. Subjective assessment of living conditions was classified as: fair, rather fair, neither fair nor poor, rather poor and poor. Information connected with cohabitation was as follows: living alone, living with a partner and/or a family. In the case of having children-children older than 15 years old, the participants answered 'yes' or 'no'.

\subsubsection{Health Status \& Health' Behaviors}

Second group of questions concerned health status and behaviors. The subjective health condition was rated as follows: fair, rather fair, neither fair nor poor, rather poor, poor. The number of health problems was divided into: none, 1-3 health problems, $4-6$ health problems and 7 and more. The respondents' weight was classified as obesity (Body Mass Index-BMI equal and over 30) and others in the case of those whose BMI was beyond 30. In the case of cigarette smoking the categories were as follows: a past smoker, an active smoker and never smoked. The participants' answers to the question on alcohol consumption were interpreted as follows: not drinking at all, a moderate and a heavy drinker.

\subsubsection{Physical Activity \& Reasons of Physical Inactivity}

Finally, there were questions related to physical activity. There were two categories of physical activity: leisure-time physical activity (LTPA) and commuting physical activity (CPA). In the assessment of LTPA, the participants were asked whether they regularly practiced any physical activities (e.g., walking, jogging, cycling, swimming, gymnastics, gardening, except for active commuting) that would last at least $30 \mathrm{~min}$. Those who did were asked to recall the frequency of such activities. The frequency of the respondents' PA weekly was divided into 4 possible answers, such as: none, occasionally, 2 to 3 days per week, and 4-7 days per week. The individuals who did not declare doing any physical exercises in their leisure time were defined as 'physically inactive' and were asked about possible reasons for their inactivity. Other information collected in the questionnaire concerned reasons for not taking up any physical activity, for example: lack of time, no willingness to exercise (I have no 
such a need), bad health condition (a disease, disability), high general physical activity (physical work, a house, a garden plot etc.), lack of money or no access to suitable facilities (a gym, playing field etc.). In the assessment of CPA, the participants were asked about the daily commuting return journey, which was divided into four categories: by using motor vehicles ( 0 min of walking or cycling), by walking or cycling for 1-14 min, by walking or cycling for 15-29 min, and by walking or cycling for $30 \mathrm{~min}$. The research covered all those who met the inclusion criteria and agreed in writing to participate in the study. A written informed consent was obtained from all the study participants, while the Bioethics Committee of the Medical University in Lodz positively reviewed the project (Project Identification Code: RNN/243/15/KE). The dataset can be found in the Supplementary Materials (SM).

Detailed characteristics of Piotrkowski District, the program assumptions and the methodology have all been published elsewhere [40].

\subsection{Characteristics of the Statistical Analyses}

The chi-square test was used to statistically analyze the four subgroups of the participants in the following age ranges: $18-29,30-39,40-49$ and 50-59. The univariable and multivariable logistic regression analyses were performed to obtain the odds ratios (ORs) and the $95 \%$ confidence interval (CI) of each indicator in relation to inactivity during leisure time and inactivity during commuting. All $p$ values were two-sided and $p<0.05$ was considered as statistically significant. The whole statistical analysis was performed by the use of the STATISTICA Windows XP version 10.0 program (StatSoft Poland Inc., Tulusa, OK, USA).

\section{Results}

Three thousand six hundred and thirty six beneficiaries of social assistance were invited to take part in the study. The final analysis included 1817 SD people (response rate $=49.8 \%$ ). The surveys with missing information were excluded.

\subsection{Baseline Characteristics of the Study Population}

Baseline characteristics of the study population are presented in Table 1. In the group of 1817 participants, there were 1224 females and 593 males with the mean age of $39.2 \pm 7.7$ years ( $38.2 \pm 7.2$ for the females and $41.1 \pm 8.1$ years for the males; $p<0.001)$. Table 1 presents the prevalence of physical inactivity during leisure time and commuting among the women and men. Characteristics of the study population also include data on the education, employment status, subjective assessment of monthly income, health status and living conditions, number of health problems, alcohol consumption, smoking cigarettes, cohabitation with somebody or living alone and having children. 
Table 1. Characteristics of the study population $(n=1817)$.

\begin{tabular}{|c|c|c|c|c|c|c|c|c|c|}
\hline \multirow[t]{2}{*}{ Variable } & \multirow[t]{2}{*}{ Total Sample } & \multicolumn{4}{|c|}{ Women } & \multicolumn{4}{|c|}{ Men } \\
\hline & & Total & Inactive LTPA & Inactive CPA & $\begin{array}{c}\text { Inactive LTPA } \\
\text { and CPA }\end{array}$ & Total & Inactive LTPA & Inactive CPA & $\begin{array}{l}\text { Inactive LTPA } \\
\text { and CPA }\end{array}$ \\
\hline Overall & $\begin{array}{c}n=1817 \\
n(\%)\end{array}$ & $\begin{array}{c}n=1224 \\
n(\%)\end{array}$ & $\begin{array}{c}\mathrm{n}=556(45.5 \%) \\
n(\%)\end{array}$ & $\begin{array}{c}n=996(81.4 \%) \\
n(\%)\end{array}$ & $\begin{array}{c}\mathrm{n}=485(39.6 \%) \\
\mathrm{n}(\%)\end{array}$ & $\begin{array}{c}\mathrm{n}=593 \\
\mathrm{n}(\%)\end{array}$ & $\begin{array}{c}\mathrm{n}=311(52.4 \%) \\
n(\%)\end{array}$ & $\begin{array}{c}n=473(79.8 \%) \\
n(\%)\end{array}$ & $\begin{array}{c}n=267(45 \%) \\
n(\%)\end{array}$ \\
\hline \multicolumn{10}{|l|}{ Age (years) } \\
\hline $18-29$ & 209(11.5) & $160(76.6)$ & 77 (48.1) & 137 (85.6) & $72(45.0)$ & $49(23.4)$ & $22(44.9)$ & 38 (77.6) & $20(40.8)$ \\
\hline $30-39$ & $778(42.8)$ & $566(72.8)$ & $253(44.7)$ & $467(82.5)$ & $221(39.0)$ & $212(27.2)$ & $120(56.6)$ & $170(80.2)$ & $104(49.0)$ \\
\hline $40-49$ & $601(33.1)$ & $385(64.1)$ & $177(46.0)$ & $304(79.0)$ & $148(38.4)$ & $216(35.9)$ & $116(53.7)$ & $174(80.6)$ & $97(44.9)$ \\
\hline $50-59$ & 229 (12.6) & $113(49.3)$ & $49(43.4)$ & $88(77.9)$ & $44(38.9)$ & $116(50.7)$ & $53(45.7)$ & $91(78.4)$ & $46(39.7)$ \\
\hline \multicolumn{10}{|l|}{ Education } \\
\hline Primary & $493(27.7)$ & $283(57.4)$ & $138(48.8)$ & $162(57.2)$ & $117(41.3)$ & $210(42.6)$ & $103(49.0)$ & $162(77.1)$ & $86(40.9)$ \\
\hline Vocational & $586(32.9)$ & $351(59.9)$ & $151(43.0)$ & $192(54.7)$ & $132(37.6)$ & $235(40.1)$ & $132(56.2)$ & $192(81.7)$ & $115(48.9)$ \\
\hline Secondary & $606(34.0)$ & 475 (78.4) & $215(45.3)$ & $106(22.3)$ & $190(40.0)$ & 131 (21.6) & $67(51.1)$ & $106(80.9)$ & $57(43.5)$ \\
\hline High & $96(5.4)$ & 88 (91.7) & $36(40.9)$ & $6(6.8)$ & $34(38.6)$ & $8(8.3)$ & $4(50.0)$ & $6(75.0)$ & $4(50.0)$ \\
\hline Missing data & $36(2.0)$ & $27(2.2)$ & $16(2.9)$ & $7(0.7)$ & $12(2.5)$ & $9(1.5)$ & $1(0.3)$ & $7(1.5)$ & $5(1.9)$ \\
\hline \multicolumn{10}{|l|}{ Employment status } \\
\hline Permanent job & $533(29.5)$ & $310(58.2)$ & $150(4.8)$ & $220(71.0)$ & $116(21.8)$ & $223(41.8)$ & $128(57.4)$ & $178(79.8)$ & $108(48.4)$ \\
\hline Temporary job & $156(8.6)$ & 85 (54.5) & $37(43.5)$ & $54(63.5)$ & $28(32.9)$ & 71 (45.5) & $32(45.1)$ & $38(54.5)$ & $21(29.6)$ \\
\hline Disabled or retired & $54(3.0)$ & $26(48.1)$ & $8(30.8)$ & $21(80.9)$ & $6(23.1)$ & $28(51.9)$ & $14(50.0)$ & $19(67.9)$ & $13(46.4)$ \\
\hline Student & $2(0.1)$ & $2(100.0)$ & $0(0.0)$ & $1(50.0)$ & $0(0.0)$ & $0(0.0)$ & $0(0.0)$ & $0(0.0)$ & $0(0.0)$ \\
\hline Unemployed & $1060(58.7)$ & 793 (74.8) & $356(44.9)$ & 693 (87.4) & $331(41.4)$ & $267(25.2)$ & 135 (50.6) & $236(88.4)$ & $123(46.1)$ \\
\hline Missing data & $12(0.7)$ & $8(0.7)$ & $5(0.9)$ & $7(0.7)$ & $4(0.8)$ & $4(0.7)$ & $2(0.6)$ & $2(0.4)$ & $2(0.7)$ \\
\hline \multicolumn{10}{|l|}{ Subjective assessment of monthly income } \\
\hline $\begin{array}{l}\text { Sufficient to cover all living needs plus may } \\
\text { save a certain amount }\end{array}$ & $20(1.1)$ & $16(80.0)$ & $2(12.5)$ & $14(87.5)$ & $2(12.5)$ & $4(20.0$ & $2(50.0)$ & $4(100.0)$ & $2(50.0)$ \\
\hline Sufficient to cover all living needs & $198(10.9)$ & $143(72.2)$ & $26(18.2)$ & $117(81.8)$ & $59(41.2)$ & $55(27.8)$ & $39(70.1)$ & $45(81.8)$ & $33(60.0)$ \\
\hline Sufficient to cover the basic living needs only & $933(51.5)$ & $650(69.7)$ & $318(48.9)$ & $546(84.0)$ & $283(43.5)$ & $283(30.3)$ & $159(56.2)$ & $224(79.1)$ & $133(47.0)$ \\
\hline Not sufficient to cover even the basic living needs & $454(25.1)$ & $266(58.6)$ & $115(43.2)$ & $206(77.4)$ & $97(36.5)$ & $188(41.4)$ & $85(45.2)$ & $151(80.3)$ & $76(40.4)$ \\
\hline Declined response difficult to say & $141(7.8)$ & $101(71.6)$ & $32(31.7)$ & $70(69.3)$ & $26(25.7)$ & $40(28.4)$ & $16(40.0)$ & $31(77.5)$ & $15(37.5)$ \\
\hline Missing data & $71(3.9)$ & $48(3.9)$ & $22(3.9)$ & $37(3.7)$ & $18(3.7)$ & $23(3.9)$ & $10(3.2)$ & $18(3.8)$ & $8(3.0)$ \\
\hline \multicolumn{10}{|l|}{ Subjective health state } \\
\hline Fair & $632(35.0)$ & $434(35.6)$ & $184(42.4)$ & $341(78.6)$ & $156(35.9)$ & $198(34.3)$ & $106(53.5)$ & $154(77.8)$ & $86(43.4)$ \\
\hline Rather fair & $559(31.0)$ & 405 (33.6) & $186(45.9)$ & $333(82.2)$ & $157(38.8)$ & $154(26.2)$ & $85(55.2)$ & $118(76.6)$ & $70(45.5)$ \\
\hline Neither fair nor poor & $420(23.3)$ & 275 (22.6) & $135(49.1)$ & $231(84.0)$ & $126(45.8)$ & $145(24.7)$ & $66(42.8)$ & $119(82.1)$ & $61(42.1)$ \\
\hline Rather poor & $141(7.8)$ & $80(6.6)$ & $36(45.0)$ & $64(80.0)$ & $33(41.2)$ & $61(10.4)$ & $34(55.7)$ & $50(82.0)$ & $32(52.4)$ \\
\hline Poor & $53(2.9)$ & $24(2.0)$ & $11(45.8)$ & $22(91.7)$ & $10(41.7)$ & $29(4.9)$ & $17(58.6)$ & $26(89.6)$ & $15(51.2)$ \\
\hline Missing data & $12(0.7)$ & $6(0.5)$ & $4(0.7)$ & $5(0.5)$ & $3(0.6)$ & $6(1.0)$ & $3(1.0)$ & $6(1.3)$ & $3(1.1)$ \\
\hline
\end{tabular}


Table 1. Cont.

\begin{tabular}{|c|c|c|c|c|c|c|c|c|c|}
\hline \multirow[t]{2}{*}{ Variable } & \multirow[t]{2}{*}{ Total Sample } & \multicolumn{4}{|c|}{ Women } & \multicolumn{4}{|c|}{ Men } \\
\hline & & Total & Inactive LTPA & Inactive CPA & $\begin{array}{c}\text { Inactive LTPA } \\
\text { and CPA }\end{array}$ & Total & Inactive LTPA & Inactive CPA & $\begin{array}{c}\text { Inactive LTPA } \\
\text { and CPA }\end{array}$ \\
\hline Overall & $\begin{array}{c}\mathrm{n}=1817 \\
\mathrm{n}(\%)\end{array}$ & $\begin{array}{c}\mathrm{n}=1224 \\
\mathrm{n}(\%)\end{array}$ & $\begin{array}{c}n=556(45.5 \%) \\
n(\%)\end{array}$ & $\begin{array}{c}n=996(81.4 \%) \\
n(\%)\end{array}$ & $\begin{array}{c}n=485(39.6 \%) \\
n(\%)\end{array}$ & $\begin{array}{c}\mathrm{n}=593 \\
\mathrm{n}(\%)\end{array}$ & $\begin{array}{c}\mathrm{n}=311(52.4 \%) \\
\mathrm{n}(\%)\end{array}$ & $\begin{array}{c}n=473(79.8 \%) \\
n(\%)\end{array}$ & $\begin{array}{c}\mathrm{n}=267(45 \%) \\
\mathrm{n}(\%)\end{array}$ \\
\hline \multicolumn{10}{|l|}{ Health problems } \\
\hline None & $245(13.7)$ & $137(11.4)$ & $62(45.2)$ & $108(78.8)$ & $54(39.4)$ & $108(18.4)$ & $62(57.4)$ & $78(72.2)$ & $48(44.4)$ \\
\hline 1-3 health problems & 968 (54.3) & 645 (53.8) & $276(42.8)$ & 519 (80.5) & $238(36.9)$ & $323(55.1)$ & $170(52.6)$ & $266(82.3)$ & $150(464)$ \\
\hline 4-6 health problems & $469(26.3)$ & $344(28.7)$ & $177(51.4)$ & $292(86.0)$ & $160(46.5)$ & $125(21.3)$ & $57(45.6)$ & $99(79.2)$ & $51(40.8)$ \\
\hline$\geq 7$ health problems & $102(5.7)$ & $72(6.0)$ & $32(44.4)$ & $59(81.9)$ & $25(34.7)$ & $30(5.1)$ & $16(53.3)$ & $23(76.6)$ & $12(40.0)$ \\
\hline M̄issing data & $33(1.8)$ & $26(2.1)$ & $9(1.6)$ & $18(1.8)$ & $8(1.6)$ & $7(1.2)$ & $6(1.9)$ & $7(1.5)$ & $6(2.2)$ \\
\hline \multicolumn{10}{|l|}{ Alcohol consumption } \\
\hline Does not drink at all & $802(46.9)$ & $619(59.2)$ & $287(46.8)$ & $481(78.4)$ & $246(40.1)$ & $189(34.1)$ & $100(52.9)$ & $144(76.2)$ & $81(42.9)$ \\
\hline Moderate drinking and heavy drinking & 905 (53.1) & $540(46.8)$ & $247(45.7)$ & $460(85.2)$ & $222(41.1)$ & $365(65.9)$ & $202(55.3)$ & $301(82.5)$ & $178(48.8)$ \\
\hline Missing data & $110(6.0)$ & $71(5.8)$ & $22(4.0)$ & $55(5.5)$ & $17(3.5)$ & $39(8.6)$ & $9(2.9)$ & $28(5.9)$ & $8(3.0)$ \\
\hline \multicolumn{10}{|l|}{ Smoking cigarettes } \\
\hline Past use & $278(15.3)$ & $178(64.0)$ & $85(47.7)$ & $143(80.3)$ & $74(41.6)$ & $100(36.0)$ & $48(48.0)$ & $85(85.0)$ & $45(45.0)$ \\
\hline Current use & $675(37.1)$ & $362(53.6)$ & $166(45.8)$ & $295(81.5)$ & $146(40.3)$ & $313(46.4)$ & $160(51.1)$ & $242(77.3)$ & $132(42.2)$ \\
\hline Never use & $864(47.6)$ & $684(79.2)$ & 305 (44.6) & $558(81.6)$ & $265(38.7)$ & $180(20.8)$ & $103(57.2)$ & $146(81.8)$ & $90(50.0)$ \\
\hline Missing data & $0(0.0)$ & $0(0.0)$ & $0(0.0)$ & $0(0.0)$ & $0(0.0)$ & $0(0.0)$ & $0(0.0)$ & $0(0.0)$ & $0(0.0)$ \\
\hline \multicolumn{10}{|l|}{ Subjective assessment of living conditions } \\
\hline Fair & $194(10.8)$ & $132(68.0)$ & $53(40.2)$ & $101(76.5)$ & $44(33.3)$ & $62(32.0)$ & $35(56.5)$ & $45(72.6)$ & $26(41.9)$ \\
\hline Rather fair & $650(360)$ & 467 (71.8) & $225(48.2)$ & $392(83.9)$ & $199(42.6)$ & $183(28.2)$ & $102(55.7)$ & $156(85.2)$ & $92(50.3)$ \\
\hline Neither fair nor poor & $815(45.2)$ & $523(64.2)$ & $226(43.2)$ & $422(80.7)$ & $197(37.7)$ & $292(35.8)$ & $152(52.0)$ & $226(77.4)$ & $131(44.9)$ \\
\hline Rather poor & $88(4.9)$ & $59(67.0)$ & $29(49.2)$ & $44(74.6)$ & $24(40.7)$ & $29(33.0)$ & $12(41.4)$ & $22(75.9)$ & $9(31.0)$ \\
\hline Poor & $33(1.3)$ & $18(54.5)$ & $11(61.1)$ & 17 (94.4) & $11(61.1)$ & $15(45.5)$ & $6(40.0)$ & $14(93.3)$ & $6(40.0)$ \\
\hline Declined response difficult to say & $23(1.3)$ & $16(69.6)$ & $7(43.7)$ & $15(93.7)$ & $7(43.7)$ & $7(30.4)$ & $2(28.6)$ & $7(100.0)$ & $2(28.6)$ \\
\hline Missing data & $14(0.8)$ & $9(0.7)$ & $5(0.9)$ & $5(0.5)$ & $3(0.6)$ & $5(0.8)$ & $2(0.6)$ & $3(0.6)$ & $1(0.4)$ \\
\hline \multicolumn{10}{|l|}{ Cohabitation with a partner and/or family } \\
\hline No (living alone) & $281(15.5)$ & $189(67.2)$ & $73(38.6)$ & $153(80.9)$ & $58(30.7)$ & $92(32.8)$ & $54(58.7)$ & $75(81.5)$ & $47(51.1)$ \\
\hline Yes & $1536(84.5)$ & 1035(67.4) & $483(46.7)$ & $843(81.4)$ & $427(41.3)$ & $501(32.6)$ & $257(51.3)$ & $398(79.4)$ & $220(43.9)$ \\
\hline \multicolumn{10}{|l|}{ Children $<15$ years } \\
\hline Yes & $1226(67.5)$ & $831(67.8)$ & $402(48.4)$ & $675(81.2)$ & $169(20.3)$ & $395(32.2)$ & $198(50.1)$ & $314(79.5)$ & $352(89.1)$ \\
\hline No & $591(32.5)$ & $393(66.5)$ & $154(39.2)$ & $321(81.7)$ & $98(24.9)$ & $198(33.5)$ & $113(57.1)$ & $159(80.3)$ & $133(67.2)$ \\
\hline \multicolumn{10}{|l|}{ Obesity } \\
\hline Yes $(\geq 30)$ & $433(23.8)$ & $289(66.7)$ & 134 (46.4) & $232(80.3)$ & $115(39.8)$ & $144(33.3)$ & $74(51.4)$ & $109(75.7)$ & $60(41.7)$ \\
\hline No $(<30)$ & $1384(76.2)$ & 935 (67.6) & $422(45.1)$ & 764 (81.7) & $370(39.6)$ & 449 (32.4) & $237(52.8)$ & $364(81.1)$ & $207(46.1)$ \\
\hline
\end{tabular}

LTPA, leisure time physical activity; CPA, commuting physical activity. 
In the study, $27.7 \%$ of the respondents had primary education (the females- $-48.8 \%$ and the males-42.6\%), 32.9\% vocational education (the females-59.9\% and the males- $40.1 \%$ ), $34 \%$ secondary education (the females-78.4\% and the males-21.6\%), and 5.4\% higher education (the females-91.7\% and the males- $8.3 \%$ ). The unemployed participants constituted a dominant group $-58.7 \%$ (the females $-74.8 \%$ and the males-25.2\%). Almost one third of the study population had a permanent job (the females- $58.2 \%$ and the males- $41.8 \%$ ), $8.6 \%$ declared having a temporary job, 3.0\% were disabled or retired, and $0.1 \%$ were female students. According to the subjective assessment of monthly income, there were only $12 \%$ of the participants who answered that they had sufficient money to cover all living needs, and only $1.1 \%$ could save a certain amount. One half of the study population had monthly income which was sufficient to cover the basic needs only and one fourth of them had insufficient income to cover even the basic needs. Only $1.3 \%$ of the women and $0.7 \%$ of the men declared that their monthly income was sufficient to cover all their living needs plus to save a certain amount and $11.7 \%$ of the women and $9.3 \%$ of the men had monthly income to cover all their living needs. Fifty three point one percent of the women and $47.7 \%$ of the men declared that their monthly income was sufficient to cover the basic needs only, and $21.7 \%$ of the women and $32.7 \%$ of the men reported that their monthly income was insufficient to cover even the basic needs.

Further data presented in Table 1 show that the subjective health condition was considered as fair by $35.0 \%$ of the participants ( $35.6 \%$ among the females and $34.4 \%$ among the males), as rather fair by $31.0 \%$ of the respondents (33.6\% among the females and $26.2 \%$ among the males), as neither fair nor poor by $23.3 \%$ ( $22.6 \%$ among the females and $24.7 \%$ among the males), as rather poor by $7.8 \%(6.6 \%$ among the females and $10.4 \%$ among the males) and as poor by $2.9 \%$ of them $(2.0 \%$ among the females and $4.9 \%$ among the males). Majority of the respondents (66\%) declared a good and a rather good health condition but health problems concerned $86.3 \%$ of the examined sample. Only $13.7 \%$ of the beneficiaries had no health problems (11.4\%-the females and $18.4 \%$-the males), $1-3$ health problems were declared by $54.3 \%$ of the respondents ( $53.8 \%$ - the females and $55.1 \%$-the males), $4-6$ health problems concerned $26.3 \%$ of them $(28.7 \%$-the females and $21.3 \%$-the males $)$, while 7 and more health problems were reported by $5.7 \%(6.0 \%$-the females and $5.1 \%$ the males).

With regard to the data on the use of alcohol and cigarette smoking, $46.9 \%$ of the study participants did not drink alcohol at all, while $53.1 \%$ drank moderately and heavily ( $46.8 \%$ of the females and $65.9 \%$ of the males). In the past, fewer social care beneficiaries smoked cigarettes-15.3\%. In the past $14.5 \%$ of women smoked cigarettes, while $16.9 \%$ of men smoked cigarettes. Now, active smokers were $37.1 \%$ ( $29.6 \%$ - the females and $52.8 \%$ - the males). Forty seven point six percent of the study participants had never smoked cigarettes (the females-55.9\% and the males-30.4\%).

Forty six point eight percent of the respondents described subjective assessment of living conditions as fair and rather fair (the females- $48.9 \%$ and the males- $41.3 \%$ ), $45.2 \%$ as neither fair nor poor (the females-42.7\% and the males-49.2\%), $4.9 \%$ as rather poor (the females- $4.8 \%$, the males- $4.9 \%$ ) and $1.8 \%$ described their living conditions as poor (the females- $1.5 \%$ and the males-2.5\%). Majority of the beneficiaries (84.5\%) lived with a partner and/or a family (the females- $84.6 \%$ and the males- $84.5 \%$ ) and most of them (67.5\%) declared having children older than 15 years old (the females- $67.8 \%$ and the males-66.6\%).

Obesity (BMI $\geq 30$ ) concerned $23.8 \%$ of the participants (the females-23.6\% and the males-24.3\%).

\subsection{Characteristic of the Prevalence of Physical Activity of (LTPA and CPA) among the Study Population}

Characteristic of physical activity during leisure time and commuting among the beneficiaries is presented in Table 2. Three fourth of the study population (73.9\%) did not meet the recommended levels of physical activity during leisure time (LTPA). More than one half $(52.4 \%)$ of the respondents stated that they had none leisure-time physical activity, and the men $(58.1 \%)$ declared it more often than the women $(49.6 \%)(p<0.05)$. There was also a statistically significant difference between the women $(23.6 \%)$ who exercised occasionally more often than the men did $(17.2 \%)(p<0.05)$. Physical 
activity during leisure time was noted more rarely among the beneficiaries, i.e., $2-3$ days weekly $(9.4 \%)$ and $4-7$ days weekly $(16.7 \%)$, in the males- $8.0 \%$ and $16.7 \%$, respectively; and in the case of females- $10.1 \%$ and $16.7 \%$, respectively; $(p>0.05)$.

Table 2. Physical activity characteristics of the study sample $(n=1817)$.

\begin{tabular}{|c|c|c|c|c|c|c|c|}
\hline \multirow{2}{*}{ Physical Activity } & \multirow{2}{*}{$\begin{array}{c}\text { Total } \\
\mathbf{n}\end{array}$} & \multirow{2}{*}{$\%$} & \multicolumn{2}{|r|}{ Women } & \multicolumn{2}{|r|}{ Men } & \multirow{2}{*}{$p$} \\
\hline & & & $\mathrm{n}$ & $\%(95 \% \mathrm{CI})$ & $\mathbf{n}$ & $\%(95 \% \mathrm{CI})$ & \\
\hline \multicolumn{8}{|l|}{ Leisure time } \\
\hline None & 867 & 52.4 & 536 & $49.6(46.7-52.5)$ & 311 & $58.1(53.9-62.3)$ & $p<0.05$ \\
\hline Occasionally & 357 & 21.5 & 265 & $23.6(21.1-26.1)$ & 92 & $17.2(14.0-20.4)$ & $p<0.05$ \\
\hline $2-3 /$ week & 156 & 9.4 & 113 & $10.1(8.3-11.7)$ & 43 & $8.0(5.7-10.3)$ & $p>0.05$ \\
\hline 4-7/week & 276 & 16.7 & 187 & $16.7(14.5-18.9)$ & 89 & $16.7(13.5-19.9)$ & $p>0.05$ \\
\hline Missing data & 161 & 8.9 & 103 & 8.4 & 58 & 9.8 & \\
\hline \multicolumn{8}{|l|}{ Commuting } \\
\hline None & 1469 & 81.8 & 996 & $82.3(80.2-84.4)$ & 473 & $80.7(77.5-83.9)$ & $p>0.05$ \\
\hline 1-14 min; (walking or cycling) per day & 172 & 9.6 & 111 & $9.2(7.6-10.8)$ & 61 & $10.4(7.9-12.9)$ & $p>0.05$ \\
\hline 15-29 min; (walking or cycling) per day & 112 & 6.2 & 75 & $6.2(4.8-7.6)$ & 37 & $6.3(4.3-8.3)$ & $p>0.05$ \\
\hline 30 min and more; (walking or cycling) per day & 43 & 2.4 & 28 & $2.3(1.5-3.1)$ & 13 & $2.6(1.3-3.9)$ & $p>0.05$ \\
\hline Missing data & 21 & 1.2 & 14 & 1.1 & 7 & 1.2 & \\
\hline
\end{tabular}

Over three fourth of the surveyed population (81.8\%) did not practice commuting physical activity. Nine point six percent of the respondents declared spending 1-14 min per day (e.g., walking or cycling) on getting to work (the females-9.2\% and the males-10.4\%). Fewer participants $(9.6 \%)$ practiced commuting physical activity for $15-29 \mathrm{~min}$ per day (the females-6.2\% and the males-6.3\%). The smallest group of the study participants practiced commuting for $30 \mathrm{~min}$ and more a day $(2.4 \%)$ (the females $-2.3 \%$ and the males $-2.6 \%$ ). There were no statistically significant differences between the males and females in any range of time needed to get to/from work in commuting PA $(p>0.05)$.

\subsection{Correlates of Lack of LTPA and CPA}

The results of the logistic regression analyses for inactivity during leisure time (LTPA) are presented in Table 3, for inactivity in commuting (CPA) in Table 4 and for both forms of physical inactivity (LTPA \& CPA) in Table 5 by sociodemographic characteristics. The Odds Ratios (OR) and the $95 \%$ Confidence Intervals $(\mathrm{CI})$ for inactivity during leisure time indicated that the men had much higher odds of leisure time physical inactivity compared to the women $(\mathrm{OR}=1.35$; 95\% CI: 1.11-1.65; $p \leq 0.01)$. There was a statistically significant difference between the e-cigarettes users. Those who did not use e-cigarettes had much higher odds of leisure time physical inactivity compared to the e-cigarettes users ( $\mathrm{OR}=2.19 ; 95 \% \mathrm{CI}: 1.12-4.25 ; p \leq 0.05)$.

Table 3. Odds ratio (OR) and $95 \%$ confidence interval (CI) for inactivity during leisure time by socio-demographic characteristics.

\begin{tabular}{|c|c|c|c|c|c|}
\hline \multirow[t]{3}{*}{ Characteristic } & \multicolumn{5}{|c|}{ Total $n=867$} \\
\hline & \multirow[b]{2}{*}{$\mathbf{N} \%$} & \multicolumn{2}{|c|}{$\begin{array}{c}\text { Univariable Logistic } \\
\text { Regression }\end{array}$} & \multicolumn{2}{|c|}{$\begin{array}{c}\text { Multivariable Logistic } \\
\text { Regression }\end{array}$} \\
\hline & & OR & $95 \% \mathrm{CI}$ & OR & $95 \% \mathrm{CI}$ \\
\hline \multicolumn{6}{|l|}{ Gender } \\
\hline Female & $556(45.4)$ & 1.00 & reference & 1.00 & reference \\
\hline Male & $311(52.5)$ & 1.32 & $1.09-1.61^{* *}$ & $1.35^{* *}$ & $1.11-1.65$ \\
\hline \multicolumn{6}{|l|}{ Smoking status } \\
\hline Smoker & $326(48.3)$ & 1.04 & $0.85-1.27$ & & \\
\hline Non-smoker & $541(47.4)$ & 1.00 & reference & 1.00 & reference \\
\hline
\end{tabular}


Table 3. Cont.

\begin{tabular}{|c|c|c|c|c|c|}
\hline \multirow[t]{3}{*}{ Characteristic } & \multicolumn{5}{|c|}{ Total $n=867$} \\
\hline & \multirow[b]{2}{*}{$\mathbf{N} \%$} & \multicolumn{2}{|c|}{$\begin{array}{l}\text { Univariable Logistic } \\
\text { Regression }\end{array}$} & \multicolumn{2}{|c|}{$\begin{array}{c}\text { Multivariable Logistic } \\
\text { Regression }\end{array}$} \\
\hline & & OR & $95 \% \mathrm{CI}$ & OR & $95 \% \mathrm{CI}$ \\
\hline \multicolumn{6}{|l|}{ Age (years) } \\
\hline$<30$ & $99(47.4)$ & 1.00 & reference & & \\
\hline $30-39$ & $373(47.9)$ & 1.02 & $0.72-1.44$ & & \\
\hline $40-49$ & $293(48.7)$ & 1.06 & $0.74-1.51$ & & \\
\hline $50-59$ & $102(44.5)$ & 0.89 & $0.60-1.33$ & & \\
\hline \multicolumn{6}{|c|}{ Subjective assessment of living condition } \\
\hline Good & $415(49.2)$ & 1.00 & reference & & \\
\hline Less than good & $445(46.4)$ & 0.89 & $0.74-1.09$ & & \\
\hline \multicolumn{6}{|l|}{ Education } \\
\hline Primary & $241(48.8)$ & 1.11 & $0.76-1.64$ & & \\
\hline Vocational & $283(48.3)$ & 1.09 & $0.74-1.59$ & & \\
\hline Secondary & $282(46.5)$ & 1.04 & $0.69-1.48$ & & \\
\hline High & $40(41.8)$ & 1.00 & reference & & \\
\hline \multicolumn{6}{|l|}{ Employment status } \\
\hline Permanent or temporary job & $347(50.4)$ & 1.00 & reference & & \\
\hline Disabled or retired & $22(40.7)$ & 0.67 & $0.38-1.18$ & & \\
\hline Unemployed & $491(46.2)$ & 0.84 & $0.70-1.02$ & & \\
\hline \multicolumn{6}{|c|}{ Subjective assessment of monthly income } \\
\hline Good & $110(50.5)$ & 1.00 & reference & & \\
\hline Less than good & $725(47.5)$ & 0.89 & $0.67-1.18$ & & \\
\hline \multicolumn{6}{|l|}{ Subjective health state } \\
\hline Good & $561(47.1)$ & 1.00 & reference & & \\
\hline Less than good & $299(48.7)$ & 1.07 & $0.88-1.30$ & & \\
\hline \multicolumn{6}{|l|}{ Health problems } \\
\hline None & $124(50.6)$ & 1.00 & reference & & \\
\hline $1-3$ health problems & $443(46.0)$ & 0.85 & $0.65-1.11$ & & \\
\hline 4-6 health problems & $234(49.9)$ & 1.00 & $0.74-1.34$ & & \\
\hline$\geq 7$ health problems & $48(47.1)$ & 0.89 & $0.56-1.40$ & & \\
\hline \multicolumn{6}{|l|}{ Alcohol consumption } \\
\hline Does not drink at all & $387(48.2)$ & 1.00 & reference & & \\
\hline $\begin{array}{l}\text { Moderate drinking and } \\
\text { heavy drinking }\end{array}$ & $449(49.6)$ & 1.06 & $0.87-1.28$ & & \\
\hline \multicolumn{6}{|c|}{ Cohabitation with a partner and/or family } \\
\hline No (living alone) & $127(45.2)$ & 1.00 & reference & & \\
\hline Yes & $740(48.2)$ & 1.13 & $0.88-1.45$ & & \\
\hline \multicolumn{6}{|l|}{ Children $<15$ years } \\
\hline Yes & $600(48.9)$ & 1.00 & reference & & \\
\hline No & $267(45.2)$ & 0.86 & $0.71-1.05$ & & \\
\hline \multicolumn{6}{|l|}{ Obesity } \\
\hline Yes $(\geq 30)$ & $208(48.0)$ & 1.02 & $0.82-1.26$ & & \\
\hline No $(<30)$ & $659(47.6)$ & 1.00 & reference & & \\
\hline
\end{tabular}

Fully adjusted model including all the statistically significant characteristics. ${ }^{* *} p \leq 0.01$. 
Table 4. Odds ratio (OR) and 95\% confidence interval (CI) for inactivity during commuting by socio-demographic characteristics.

\begin{tabular}{|c|c|c|c|c|c|}
\hline \multirow[t]{3}{*}{ Characteristic } & \multicolumn{5}{|c|}{ Total $n=1469$} \\
\hline & \multirow[b]{2}{*}{$\mathbf{N} \%$} & \multicolumn{2}{|c|}{$\begin{array}{c}\text { Univariable Logistic } \\
\text { Regression }\end{array}$} & \multicolumn{2}{|c|}{$\begin{array}{c}\text { Multivariable Logistic } \\
\text { Regression }\end{array}$} \\
\hline & & OR & $95 \% \mathrm{CI}$ & OR & $95 \% \mathrm{CI}$ \\
\hline \multicolumn{6}{|l|}{ Gender } \\
\hline Female & $996(81.4)$ & 1.00 & reference & & \\
\hline Male & $473(79.8)$ & 0.90 & $0.70-1.15$ & & \\
\hline \multicolumn{6}{|l|}{ Smoking status } \\
\hline Smoker & $537(79.6)$ & 0.88 & $0.69-1.11$ & & \\
\hline Non-smoker & $932(81.6)$ & 1.00 & reference & & \\
\hline \multicolumn{6}{|l|}{ Age (years) } \\
\hline$<30$ & $175(83.7)$ & 1.00 & reference & & \\
\hline $30-39$ & $637(81.9)$ & 0.88 & $0.58-1.32$ & & \\
\hline $40-49$ & 478 (79.5) & 0.76 & $0.50-1.15$ & & \\
\hline $50-59$ & $179(78.2)$ & 0.70 & $0.43-1.13$ & & \\
\hline \multicolumn{6}{|c|}{ Subjective assessment of living condition } \\
\hline Good & $694(82.2)$ & 1.00 & reference & & \\
\hline Less than good & $767(80.0)$ & 0.86 & $0.68-1.09$ & & \\
\hline \multicolumn{6}{|l|}{ Education } \\
\hline Primary & $27(75.0)$ & $0.49 * *$ & $0.27-0.86$ & $0.34^{* * *}$ & $0.18-0.64$ \\
\hline Vocational & $463(79.0)$ & $0.48^{* *}$ & $0.27-0.86$ & $0.44 * *$ & $0.24-0.80$ \\
\hline Secondary & $500(82.5)$ & 0.60 & $0.34-1.08$ & $0.54 *$ & $0.29-0.99$ \\
\hline High & $90(93.7)$ & 1.00 & reference & 1.00 & reference \\
\hline \multicolumn{6}{|l|}{ Employment status } \\
\hline Permanent or temporary job & $490(71.1)$ & 1.00 & reference & 1.00 & reference \\
\hline Disabled or retired & $40(74.1)$ & 1.15 & $0.61-2.17$ & 1.43 & $0.71-2.87$ \\
\hline Unemployed & $930(87.6)$ & $2.85^{* * *}$ & $2.23-3.64$ & $3.41^{* * *}$ & $2.59-4.48$ \\
\hline \multicolumn{6}{|c|}{ Subjective assessment of monthly income } \\
\hline Good & $186(85.3)$ & 1.00 & reference & & \\
\hline Less than good & $1228(80.4)$ & 0.70 & $0.47-1.05$ & & \\
\hline \multicolumn{6}{|l|}{ Subjective health state } \\
\hline Good & $946(79.4)$ & 1.00 & reference & 1.00 & reference \\
\hline Less than good & $512(83.4)$ & $1.30^{*}$ & $1.01-1.68$ & 1.35 & $0.99-1.84$ \\
\hline \multicolumn{6}{|l|}{ Health problems } \\
\hline None & $186(75.9)$ & 1.00 & reference & 1.00 & reference \\
\hline $1-3$ health problems & $781(81.2)$ & $1.38^{*}$ & $1.01-1.90$ & 1.37 & $0.97-1.93$ \\
\hline $4-6$ health problems & $391(83.4)$ & $1.61 * *$ & $1.12-2.32$ & 1.33 & $0.88-2.02$ \\
\hline$\geq 7$ health problems & $82(80.4)$ & 1.32 & $0.75-2.30$ & 1.03 & $0.54-1.94$ \\
\hline \multicolumn{6}{|l|}{ Alcohol consumption } \\
\hline Does not drink at all & $625(77.9)$ & 1.00 & reference & 1.00 & reference \\
\hline $\begin{array}{l}\text { Moderate drinking and } \\
\text { Heavy drinking }\end{array}$ & $761(84.1)$ & $1.49^{* * *}$ & $1.17-1.91$ & $1.86^{* * *}$ & $1.43-2.41$ \\
\hline \multicolumn{6}{|c|}{ Cohabitation with a partner and/or family } \\
\hline No (living alone) & $228(81.3)$ & 1.00 & reference & 1.00 & reference \\
\hline Yes & $1241(84.1)$ & 0.98 & $0.73-1.32$ & & \\
\hline \multicolumn{6}{|l|}{ Children $<15$ years } \\
\hline Yes & $989(80.7)$ & 1.00 & reference & & \\
\hline No & $480(81.2)$ & 1.03 & $0.80-1.35$ & & \\
\hline \multicolumn{6}{|l|}{ Obesity } \\
\hline Yes $(\geq 30)$ & $341(78.7)$ & 0.84 & $0.64-1.10$ & & \\
\hline No $(<30)$ & $1128(81.5)$ & 1.00 & reference & & \\
\hline
\end{tabular}

Fully adjusted model including all the statistically significant characteristics. ${ }^{*} p \leq 0.05 .{ }^{* *} p \leq 0.01 .{ }^{* * *} p \leq 0.001$. 
Table 5. Odds ratio (OR) and 95\% confidence interval (CI) for inactivity during leisure time and during commuting by socio-demographic characteristics.

\begin{tabular}{|c|c|c|c|c|c|}
\hline \multirow[t]{3}{*}{ Characteristic } & \multicolumn{5}{|c|}{ Total $(n=1817)$} \\
\hline & \multirow[b]{2}{*}{$\mathbf{N} \%$} & \multicolumn{2}{|c|}{$\begin{array}{c}\text { Univariable Logistic } \\
\text { Regression }\end{array}$} & \multicolumn{2}{|c|}{$\begin{array}{c}\text { Multivariable Logistic } \\
\text { Regression }\end{array}$} \\
\hline & & OR & $95 \% \mathrm{CI}$ & OR & $95 \% \mathrm{CI}$ \\
\hline \multicolumn{6}{|l|}{ Gender } \\
\hline Female & $485(39.6)$ & 1.00 & reference & 1.00 & reference \\
\hline Male & $267(45.0)$ & $1.25 *$ & $1.02-1.52$ & $1.22 *$ & $1.00-1.50$ \\
\hline \multicolumn{6}{|l|}{ Smoking status } \\
\hline Smoker & $278(41.2)$ & 0.99 & $0.81-1.20$ & & \\
\hline Non-smoker & $478(41.5)$ & 1.00 & reference & 1.00 & reference \\
\hline \multicolumn{6}{|l|}{ Age (years) } \\
\hline$<30$ & $92(44.0)$ & 1.00 & reference & & \\
\hline $30-39$ & $325(4.8)$ & 0.91 & $0.67-1.24$ & & \\
\hline $40-49$ & $245(40.8)$ & 0.88 & $0.64-1.20$ & & \\
\hline $50-59$ & $90(39.3)$ & 0.82 & $0.56-1.21$ & & \\
\hline \multicolumn{6}{|c|}{ Subjective assessment of living condition } \\
\hline Good & $361(42.8)$ & 1.00 & reference & & \\
\hline Less than good & $387(40.4)$ & 0.91 & $0.75-1.09$ & & \\
\hline \multicolumn{6}{|l|}{ Education } \\
\hline Primary & $203(41.2)$ & 1.01 & $0.66-1.45$ & & \\
\hline Vocational & $247(42.2)$ & 1.08 & $0.69-1.50$ & & \\
\hline Secondary & $247(40.8)$ & 1.01 & $0.66-1.41$ & & \\
\hline High & $38(39.6)$ & 1.00 & reference & & \\
\hline \multicolumn{6}{|l|}{ Employment status } \\
\hline Permanent or temporary job & $273(39.6)$ & 1.00 & reference & & \\
\hline Disabled or retired & $19(35.2)$ & 0.82 & $0.46-1.47$ & & \\
\hline Unemployed & $454(42.8)$ & 1.13 & $0.93-1.37$ & & \\
\hline \multicolumn{6}{|c|}{ Subjective assessment of monthly income } \\
\hline Good & $96(44.0)$ & 1.00 & reference & & \\
\hline Less than good & $630(41.2)$ & 0.89 & $0.67-1.19$ & & \\
\hline \multicolumn{6}{|l|}{ Subjective health state } \\
\hline Good & $469(39.4)$ & 1.00 & reference & 1.00 & reference \\
\hline Less than good & $277(45.1)$ & $1.27^{*}$ & $1.04-1.54$ & 1.24 * & $1.02-1.52$ \\
\hline \multicolumn{6}{|l|}{ Health problems } \\
\hline None & $102(41.6)$ & 1.00 & reference & & \\
\hline $1-3$ health problems & $386(40.1)$ & 0.94 & $0.72-1.23$ & & \\
\hline 4-6 health problems & $211(45.0)$ & 1.15 & $0.85-1.55$ & & \\
\hline$\geq 7$ health problems & $37(36.3)$ & 0.80 & $0.50-1.29$ & & \\
\hline \multicolumn{6}{|l|}{ Alcohol consumption } \\
\hline Does not drink at all & $327(40.8)$ & 1.00 & reference & & \\
\hline $\begin{array}{l}\text { Moderate drinking and } \\
\text { heavy drinking }\end{array}$ & $400(44.2)$ & 1.15 & $0.95-1.39$ & & \\
\hline \multicolumn{6}{|c|}{ Cohabitation with a partner and/or family } \\
\hline No (living alone) & $105(37.4)$ & 1.00 & reference & & \\
\hline Yes & $647(42.1)$ & 1.22 & $0.94-1.58$ & & \\
\hline \multicolumn{6}{|l|}{ Children $<15$ years } \\
\hline Yes & $521(42.5)$ & 1.00 & reference & & \\
\hline No & $231(39.1)$ & 0.87 & $0.71-1.06$ & & \\
\hline \multicolumn{6}{|l|}{ Obesity } \\
\hline Yes $(\geq 30)$ & $175(40.4)$ & 0.95 & $0.76-1.18$ & & \\
\hline No $(<30)$ & $588(41.7)$ & 1.00 & reference & & \\
\hline
\end{tabular}

Fully adjusted model including all the statistically significant characteristics. ${ }^{*} p \leq 0.05$. 
Physical inactivity during commuting looked different. The Odds Ratios (OR) and the 95\% Confidence Intervals (CI) for commuting inactivity showed that the level of education played a significant role. The study participants with primary, vocational and secondary education had higher odds of commuting inactivity than the participants with a high level education (for the primary education $\mathrm{OR}=0.34 ; 95 \%$ CI: $0.18-0.64 ; p \leq 0.001$; for vocational education OR $=0.44 ; 95 \%$ CI: $0.24-0.80$; $p \leq 0.01$ and for secondary education OR $=0.54 ; 95 \%$ CI: 0.29-0.99; $p \leq 0.05)$. The unemployed study participants had much higher odds of inactivity CPA than those beneficiaries who had a permanent or a temporary job (OR $=3.41 ; 95 \% \mathrm{CI}$ : $2.59-4.48 ; p \leq 0.05)$. Also the respondents who consumed alcohol had higher odds of inactivity CPA than those who did not drink alcohol (OR $=1.86$; 95\% CI: 1.43-2.41; $p \leq 0.001$ ).

The Odds Ratios (OR) and the 95\% Confidence Intervals (CI) for inactivity during leisure time (LTPA) and during commuting (CPA) together, once again, showed that the men had much higher odds of physical inactivity during leisure time (LTPA) and commuting (CPA) compared to physical inactivity of the women (OR $=1.22 ; 95 \%$ CI: $1.00-1.50 ; p \leq 0.05)$.

\subsection{Reasons for Not Taking Up Physical Activity among the Study Population}

Reasons for physical inactivity among the beneficiaries are presented in Table 6.

Table 6. Reasons for not taking up leisure time physical activity (LTPA) by the examined participants.

\begin{tabular}{lcccc}
\hline Reasons & $\begin{array}{c}\text { Total } \mathbf{n}=\mathbf{8 6 2} \\
\mathbf{n}(\%)\end{array}$ & $\begin{array}{c}\text { Women } \mathbf{n}=\mathbf{5 5 2} \\
\mathbf{n}(\mathbf{\%})\end{array}$ & $\begin{array}{c}\text { Men } \mathbf{n}=\mathbf{3 1 1} \\
\mathbf{n}(\mathbf{\%})\end{array}$ & $\mathbf{p}$ \\
\hline Lack of time & $242(28.1)$ & $170(30.8)$ & $72(23.2)$ & 0.0172 \\
\hline $\begin{array}{l}\text { No willingness to exercise } \\
\text { (I have no such a need) }\end{array}$ & $219(25.4)$ & $149(27.0)$ & $70(22.6)$ & 0.1545 \\
\hline $\begin{array}{l}\text { Bad health condition } \\
\text { (a disease, disability) }\end{array}$ & $105(12.2)$ & $48(8.7)$ & $57(18.4)$ & 0.0000 \\
\hline $\begin{array}{l}\text { High general PA } \\
\text { (physical work, a house, a garden plot etc.) }\end{array}$ & $314(36.4)$ & $201(36.4)$ & $113(36.5)$ & 0.9766 \\
\hline Lack of money & $30(3.5)$ & $20(3.6)$ & $10(3.2)$ & 0.7577 \\
\hline $\begin{array}{l}\text { No access to suitable facilities } \\
\text { (a gym, playing field etc.) }\end{array}$ & $21(2.4)$ & $14(2.5)$ & $7(2.3)$ & 0.8547 \\
\hline Other reasons & $1(0.1)$ & $1(0.2)$ & $0(0.0)$ & 0.4308 \\
\hline Missing data & $5(0.6)$ & $4(0.7)$ & $1(0.3)$ & - \\
\hline
\end{tabular}

The most common reason why participants did not take up physical activity was high general physical activity (e.g., physical work, a house, a garden plot etc.). This particular reason referred to $36.4 \%$ of the examined sample ( $36.4 \%$-the females and $36.5 \%$ of the males). There was not a statistically significant difference between the women and men $(p>0.97)$. The further two important reasons why the beneficiaries did not exercise were: lack of time- $28.1 \%$ (the females-30.8\% and $23.2 \%$-the males) and no willingness to exercise-25.4\% (27.0\%-the females and $22.6 \%$-the males). The women declared lack of time to exercise more frequently than the men did and the difference was statistically significant $(p<0.017)$. Other reasons were: bad health condition (a disease, disability) $-12.2 \%$ of the study group (the females $-8.7 \%$ and the males $-18.4 \%$ ), lack of money-3.5\% (the females $-3.6 \%$ and $3.2 \%$ the males), and no access to suitable facilities (a gym, playing field etc.) $-2.4 \%$ (the females $-2.5 \%$, and the males-2.3\%).

\section{Discussion}

The present study examined the prevalence of physical activity (LTPA and CPA) among the adult beneficiaries of government welfare assistance in Poland. It also collected data on the reasons of inactivity among the studied population. The results showed that $52.4 \%$ of the participants had 
none physical activity during leisure time and $81.8 \%$ had no physical activity during commuting. Comparing these results to the general population of Poland, it appears that the prevalence of physical inactivity (LTPA) among the beneficiaries of welfare group is 1.5 times higher than in the general population [41]. In addition, three fourth of the study participants did not reach the physical activity recommendation level in LPTA (73.9\%). What is more, four fifth of the participants also did not meet the recommended level of commuting CPA $(91.4 \%)$. Both cases of physical inactivity (LTPA \& CPA) were also higher when compared to the general population [41].

Only $16.7 \%$ of the respondents exercised between $4-7$ times weekly during their leisure time (LTPA). The prevalence of regular physical activity (more days weekly) among the beneficiaries was twice time lower than it was among adults in the general population of Poles [41].

On the other hand, the prevalence of active commuting (CPA) lasting all the studied time periods ( $<15 \mathrm{~min}, 15-30 \mathrm{~min}$ and $>30 \mathrm{~min}$ and more) was several times lower among the beneficiaries than it was in the general population [12,41].

In studied group, the men did not practice LTPA more frequently when compared to the women, contrary to the situation in the general population of Poland, where inactivity is more common among women than men [41]. However, in the case of inactivity during commuting (CPA), in the socially disadvantaged group higher inactivity was reported among the women than in the men. The same has been observed in the general population of Poland [11,41].

A study conducted by Marques A. et al., in 28 European countries among adults (18-65 years) has shown that physical activity recommended levels were attained by $64.5 \%$ of the study participants, and similarly to the general Polish population, women exercised more often than men did $(66.49 \%$ vs. $63.36 \%)$ [17]. Although research in several countries (e.g., Portugal, The Netherlands, Luxembourg, France, Belgium) has shown a slightly higher physical activity among women than men; in our study the situation was opposite. It could be associated with the fact that the socially disadvantaged women had more workload at home and in a different way shared the time devoted to responsibilities. Further data of our study indicated that the socially disadvantaged women declared not taking up PA because of lack of time. In our study, age, subjective assessment of living conditions, subjective assessment of monthly income and of health status as well as cohabitation with a partner and/or family, having children, obesity as well as smoking status were factors, which were not correlated with physical inactivity during leisure-time and commuting among the adult beneficiaries of government welfare assistance in Poland.

The multivariable analyses indicated only four significant factors correlated with physical inactivity. During leisure-time (LTPA) physical inactivity correlated positively with male gender, and during commuting PA (CPA) with the level of education, employment status, health problems and alcohol consumption. The men had a 1.3 higher risk of not doing physical exercises than the women and, they declared a bad health condition more often than the lack of time $(p<0.05)$. In the general population of Poland, men suffer from non-communicable diseases more frequently than women. Physical inactivity constitutes a serious risk factor for the disadvantaged men to develop non-communicable diseases earlier and more frequently than the women. The socially disadvantaged groups are unaware of consequences of physical inactivity because of lack of knowledge and not understanding the risk of developing a coronary heart disease [42].

Another significant correlate of physical inactivity during commuting PA (CPA), which was indicated by the multivariable analyses, was the level of education. The individuals with a higher level of education were statistically least likely to use CPA when compared to the people with a secondary ( $\mathrm{OR}=0.54 ; 95 \% \mathrm{Cl} 0.29-0.99 p<0.05)$, vocational $(\mathrm{OR}=0.44 ; 95 \% \mathrm{Cl} 0.24-0.80 p<0.01)$ and a primary level of education (OR $=0.34 ; 95 \% \mathrm{Cl} 0.18-0.64 p<0.001)$. We can only suppose that in our study it was associated with the presence of more than one vehicle in a household, similarly to the studies conducted among adult Brazilians and people living in six middle income countries, where the vehicles constituted a reason both in the case of men and women for being physically inactive during commuting [22,43]. 
It is surprising as it seems that highly educated people should have knowledge on health benefits of physical activity [44]. In our study the highly educated individuals did not exercise in leisure time more often than the persons with lower education $(p>0.05)$. In the study described in the paper, commuting physical activity (CPA) was negatively associated with being unemployed (odds ratio even free times higher- $\mathrm{OR}=3.41 ; 95 \% \mathrm{Cl} 2.59-4.48 p<0.05$ ) [17] and being a moderate and heavy drinker of alcohol (odds ratio almost twice times higher- $\mathrm{OR}=1.86 ; 95 \% \mathrm{Cl} 1.43-2 . p<0.001$ ). This is in agreement with results of the study performed among Canadians, which has shown that the adults who drank alcohol were less physically active [45].

The univariable logistic regression showed that the disadvantaged people who had health problems $(1-3$ problems $\mathrm{OR}=1.38 ; 95 \% \mathrm{Cl} 1.01-1.90 p<0.05$, and $4-6$ problems $\mathrm{OR}=1.61$; $95 \% \mathrm{Cl} 1.12-2.32 p<0.01$ ) were less likely to be active when compared to the healthy individuals. A meta-analysis by O'Mara-Eves A. et al has shown that a worse health condition in disadvantaged groups was observed in many developed countries, where they had worse health outcomes such as lower life expectancy than non-disadvantaged groups [46]. After an effective commuting intervention they successfully managed to increase self-efficacy of disadvantaged group in terms of health consequences and health behavior [46]. It is worth to use both forms of physical activity, i.e., LTPA and CPA, as they are both extremely important with respect to the primary and secondary prevention of CVD. Moreover, they make it easier to deal with daily tasks (such as climbing stairs and shopping), they improve well-being and contribute considerably to an increase in life expectancy $[47,48]$. Finally, one more of the most important findings of the study was getting to know the reasons why the adult beneficiaries of government welfare assistance in Poland are physically inactive. The most often declared reason for physical inactivity was a high general physical activity (physical work, a house, a garden plot etc.), both among the men and women $(p>0.05)$. Then, there were: lack of time $(31 \%$ of the females vs. $23.2 \%$ of the men, $p<0.05)$, no willingness to exercise $(27 \%$ of the females vs. $22.6 \%$ of the men, $p>0.05$ ) and bad health condition (a disease, disability $-8.7 \%$ of the females vs. $18.4 \%$ of the men, $p<0.05$ ). Only $3.5 \%$ of the studied disadvantaged group declared lack of money as a reason for physical inactivity and $2.4 \%$ of them mentioned access to suitable facilities (a gym, playing field etc.). There were no statistical differences between the female and male participants of the study, both in the case of lack of money and access to facilities $(p>0.05)$. Lack of time for PA (and LTPA) is characteristic not only for the disadvantaged population. Results of the reasons for physical inactivity are similar in general Polish population and related to lack of time $(26.7 \%)$, poor health $(24.3 \%)$ and no willingness/interest to exercise (24\%) [42]. Also in the case of people with higher education and a higher occupation status, being sufficiently physically active during their leisure time was a significant problem [44]. However, in the case of the socially disadvantaged group, physical activity can result in higher self-efficacy than necessary to overcome daily difficulties [44].

Recommendations in systematic reviews, where the amount, frequency, intensity and a type of physical activity have been examined, required to achieve physical and mental health benefits in the adult population, consistently indicate a weekly volume of 150 min of moderate intensity physical activity. The most significant thing is that this overall volume of physical activity is more important than the specific type of activity, its intensity or frequency of sessions. For example: gardening is a great way to enjoy some fresh air, it is fun, creative and helps to manage stress. However, gardening is hardly pumping iron and it probably won't do much good for you in terms of cardiovascular fitness. On the other hand, digging, planting, weeding, and other repetitive tasks that require strength or stretching are excellent forms of a low-impact exercise (can help strengthen bones and joints), especially in the case of people who find more vigorous exercise a challenge, such as those who are older, have disabilities or those who suffer from chronic pain [49-51]. Different types of housework constitute another example: ironing, cleaning and dusting (performed by women more frequently). They are of light intensity and are associated with energy expenditure (hoovering moderate intensity). Nevertheless, they are boring, monotonous, static, tiring and often involve only some groups of muscles, which results from a forced body position and they do not result in the desired health effects. What is more, they are 
often performed due to such a necessity and not because people like doing them, which is the most important thing when it comes to improving health by being physically active [49-51].

Humans are not programmed for a sedentary lifestyle. Physical activity has well-documented health benefits in the primary, secondary and tertiary prevention of non-communicable diseases, and it is recommended as a factor improving prognosis. Cohort studies have proved the fact that a high level of leisure time physical activity (LTPA) results in a significant reduction in the prevalence of both coronary heart disease and stroke in both sexes [2]. The adult beneficiaries of government welfare assistance should have this basic knowledge in order to be more motivated to do physical exercises and to experience numerous health benefits of it.

\section{Strengths and Limitations of the Study}

The current analysis has several strengths. Firstly, the study was conducted among the socially disadvantaged population of social assistance beneficiaries from a rural district of Poland. Secondly, a large group of beneficiaries aged 18-59 (3636 persons) were invited to take part in the study. Finally, one half of the invited group participated in the survey. The response rate was almost $50 \%$ (response rate $=49.8 \%$ ) of the average level compared to other questionnaire surveys conducted in Poland. Another important strength of the study is the fact that it examined the prevalence of physical activity among the beneficiaries of government welfare assistance, both during leisure time and during commuting. It is the study where for the first time both types of physical activity have been examined with regard to this characteristic group in Poland. In general, there are not many studies that have examined both types of physical activity in a disadvantaged population, not to mention studies conducted in Poland. The fact that the study examined a number of determinants that can influence physical inactivity among the study population is its yet another strength. Finally, the study results will be of great importance when developing physical activity programs addressed to this special group (and not to the general population), which will most probably translate into their efficiency and success.

Limitations of the study include the fact that it examined the participants only at a single point in time, i.e., now. We know nothing about physical activity among the examined beneficiaries in the past, e.g., practiced sports, education in school and home environment, which could have determined their physical activity in the future. In order to result in health benefits, physical intervention should be long-term and it cannot only cover one or several months. It is difficult to start regular exercise but it is even more difficult to maintain physical activity for years. Another limitation of the study refers to the questions used in the survey. The questionnaire consisted of several parts of questions but all of them were direct questions, which required one answer from the participants or had to be missed out. More open questions could help to find out about the needs and barriers that this group of respondents has. Self-reporting nature of the process of data collection is associated with the evident risk of recall bias and this is also a limitation of the study that has to be mentioned.

\section{Conclusions}

The prevalence of physical inactivity (both LTPA and CPA) among the social assistance recipients is much higher than in the general population. Therefore, especially rural disadvantaged residents are undoubtedly an appropriate target group for future physical activity interventions. Several factors significantly correlate with the physical inactivity in this socio-demographic group. When promoting an active lifestyle (PA leisure-time and/or commuting) and prevention of non-communicable diseases we should remember about these factors and pay attention to substantial differences between the general population and the socially disadvantaged individuals. Improved continued monitoring of physical activity is required. Furthermore, continuing surveillance among general and vulnerable populations is necessary to evaluate motivators and barriers towards active living.

Supplementary Materials: The following are available online at www.mdpi.com/1660-4601/14/10/1126/s1. 
Acknowledgments: The study has been funded as part of the Program PL-13 “Reducing Social Inequalities in Health" project supported by a grant from Norway through Norway Grants, and co-financed by the Polish state budget; "Your heart is your life" (grant number: PL13-27/032/13/NMF/2015/00/2802/678). Written permission has been provided for the use of the data. The funding body had no role in the design of the study, collection, analysis and interpretation of the data and in writing the manuscript.

Author Contributions: Dorota Kaleta was the Principal Investigator of the Project (grant number: PL13-27/032/13/NMF/2015/00/2802/678), conceived the original idea for the analysis, participated in the interpretation of the results, co-drafted the paper and contributed intellectually to the development of the final manuscript. Sylwia Kalucka undertook the literature search, participated in the interpretation of the results, and co-drafted the paper. Franciszek Szatko read the draft. Teresa Makowiec-Dabrowska commented on draft. All the authors have read and approved the final paper.

Conflicts of Interest: The authors declare no conflict of interest.

\section{Abbreviations}

PA physical activity

LTPA leisure time physical activity

CPA commuting physical activity

\section{References}

1. Li, J.; Siegrist, J. Physical Activity and Risk of Cardiovascular Disease-A Meta-Analysis of Prospective Cohort Studies. Int. J. Environ. Res. Public Health 2012, 9, 391-407. [CrossRef] [PubMed]

2. Craig, C.L.; Lambert, E.V.; Inoue, S.; Alkandari, J.R.; Leetongin, G.; Kahlmeier, S. The pandemic of physical inactivity: Global action for public health. Lancet 2012, 380, 294-305.

3. Lee, I.M.; Shiroma, E.J.; Lobelo, F.; Puska, P.; Blair, S.N.; Katzmarzyk, P.T. Effect of physical inactivity on major non-communicable diseases worldwide: An analysis of burden of disease and life expectancy. Lancet 2012, 380, 219-229. [CrossRef]

4. Gonçalves, A.K.; Dantas Florencio, G.L.; Maisonnette de Atayde Silva, M.J.; Cobucci, R.N.; Giraldo, P.C.; Cote, N.M. Effects of physical activity on breast cancer prevention: A systematic review. J. Phys. Act. Health 2014, 11, 445-454. [CrossRef] [PubMed]

5. Lahart, I.M.; Metsios, G.S.; Nevill, A.M; Carmichael, A.R. Physical activity, risk of death and recurrence in breast cancer survivors: A systematic review and meta-analysis of epidemiological Studies. Acta Oncol. 2015, 54, 635-654. [CrossRef] [PubMed]

6. Schoenberg, M.H. Physical Activity and Nutrition in Primary and Tertiary Prevention of Colorectal Cancer. Visc. Med. 2016, 32, 199-204. [CrossRef] [PubMed]

7. Teychenne, M.; Ball, K.; Salmon, J. Physical activity, sedentary behaviour and depression among disadvantaged women. Health Educ. Res. 2010, 25, 632-644. [CrossRef] [PubMed]

8. Directorate-General for Education and Culture, European Commission. Special Eurobarometer 412. Sport and Physical Activity Report; European Commission: Brussels, Belgium, 2014. [CrossRef]

9. Hallal, P.C.; Andersen, L.B.; Bull, F.C.; Guthold, R.; Haskell, W.; Ekelund, U. Global physical activity levels: Surveillance progress, pitfalls, and prospects. Lancet 2012, 380, 247-257. [CrossRef]

10. Woitas-Ślubowska, D.; Hurnik, E.; Skarpańska-Stejnborn, A. Correlates of smoking with socioeconomic status, leisure time physical activity and alcohol consumption among polish adults from randomly selected regions. Cent. Eur. J. Public Health 2010, 18, 179-185. [PubMed]

11. Drygas, W.; Sakłak, W.; Kwaśniewska, M.; Bandosz, P.; Rutkowski, M.; Bielecki, W.; Rębowska, E.; Prusik, K.; Zdrojewski, T. Epidemiology of physical activity in adult Polish population in the second decade of the 21st century. Results of the NATPOL 2011 study. Int. J. Occup. Med. Environ. Health 2013, 26, 846-855. [CrossRef] [PubMed]

12. WHO. A Comprehensive Global Monitoring Framework and Voluntary Global Targets for the Prevention and Control of NCDs. World Health Organisation, 2011. Available online: http://www.who.int/nmh/ events/2011/consultation_dec_2011/WHO (accessed on 21 December 2011).

13. European Union. 2008 EU Physical Activity Guidelines Recommended Policy Actions in Support of Health-Enhancing Physical Activity; European Union: Brussels, Belgium, 2008. 
14. USDHHS. 2008 Physical Activity Guidelines for Americans. Be Active, Healthy, and Happy! USDHHS: Washington, DC, USA, 2008.

15. WHO. Global Recommendations on Physical Activity for Health; World Health Organization: Geneva, Switzerland, 2010.

16. Solomon, E.; Rees, T.; Ukoumunne, O.C.; Metcalf, B.; Hillsdon, M. Personal, social, and environmental correlates of physical activity in adults living in rural south-west England: A cross-sectional analysis. Int. J. Behav. Nutr Phys. Act. 2013, 10, 129. [CrossRef] [PubMed]

17. Marques, A.; Martins, J.; Peralta, M.; Catunda, R.; Nunes, L.S. European adults' physical activity sociodemographic correlates: A cross-sectional study from the European Social Survey. PeerJ 2016, 4, e2066. [CrossRef] [PubMed]

18. Parks, S.E.; Housemann, R.A.; Brownson, R.C. Differential correlates of physical activity in urban and rural adults of various socioeconomic backgrounds in the United States. J. Epidemiol. Community Health 2003, 57, 29-35. [CrossRef] [PubMed]

19. Wilcox, S.; Castro, C.; King, A.C.; Housemann, R.; Brownson, R.C. Determinants of leisure time physical activity in rural compared with urban older and ethnically diverse women in the United States. J. Epidemiol. Community Health 2000, 54, 667-672. [CrossRef] [PubMed]

20. Eyler, A.A. Personal, social, and environmental correlates of physical activity in adults living in rural Midwestern white women. Am. J. Prev. Med. 2003, 25, 86-92. [CrossRef]

21. Kirk, M.A.; Rhodes, R.E. Occupation correlates of adults' participation in leisure-time physical activity: A systematic review. Am. J. Prev. Med. 2011, 40, 476-485. [CrossRef] [PubMed]

22. Sa, T.H.; Salvador, E.P.; Florindo, A.A. Factors associated with physical inactivity in transportation in Brazilian adults living in a low socioeconomic area. J. Phys. Act. Health 2013, 10, 856-862. [CrossRef] [PubMed]

23. Amin, T.T.; Suleman, W.; Ali, A.; Gamal, A.; Al Wehedy, A. Pattern, prevalence, and perceived personal barriers toward physical activity among adult Saudis in Al-Hassa, KSA. J. Phys. Act. Health 2011, 8, 775-784. [CrossRef] [PubMed]

24. Kwaśniewska, M.; Pikala, M.; Bielecki, W.; Dziankowska-Zaborszczyk, E.; Rębowska, E.; Kozakiewicz, K.; Pająk, A.; Piwoński, J.; Tykarski, A.; Zdrojewski, T.; et al. Ten-Year Changes in the Prevalence and Socio-Demographic Determinants of Physical Activity among Polish Adults Aged 20 to 74 Years. Results of the National Multicenter Health Surveys WOBASZ (2003-2005) and WOBASZII (2013-2014). PLoS ONE 2016, 11, 6 .

25. Beenackers, M.A.; Kamphuis, C.B.M.; Giskes, K.; Brug, J.; Kunst, A.E.; Burdorf, A.; van Lenthe, F.J. Socioeconomic inequalities in occupational, leisure-time, and transport related physical activity among European adults: A systematic review. Int J. Behav. Nutr. Phys. Act. 2012, 9, 116. [CrossRef] [PubMed]

26. Bauman, A.; Ma, G.; Cuevas, F.; Omar, Z.; Waqanivalu, T.; Phongsavan, P.; Keke, K.; Bhushan, A. Cross-national comparisons of socioeconomic differences in the prevalence of leisure-time and occupational physical activity, and active commuting in six Asia-Pacific countries. J. Epidemiol. Community Health 2011, 65, 35-43. [CrossRef]

27. Mummery, W.K.; Lauder, W.; Schofield, G.; Caperchione, C. Associations between physical inactivity and a measure of social capital in a sample of Queensland adults. J. Sci. Med. Sport 2008, 11, 308-315. [CrossRef] [PubMed]

28. Teuschera, D.; Bukmanb, A.J.; van Baaka, A.M.; Feskens, E.J.; Renes, R.J.; Meershoek, A. Challenges of a healthy lifestyle for socially disadvantaged people of Dutch, Moroccan and Turkish origin in the Netherlands: A focus group study. Crit. Public Health 2015, 25, 615-626. [CrossRef] [PubMed]

29. Kahan, E.; Fogelman, Y.; Bloch, B. Correlations of work, leisure, and sports physical activities and health status with socioeconomic factors: A national study in Israel. Postgrad. Med. J. 2005, 81, 262-265. [CrossRef] [PubMed]

30. Yoshinobu, S.; Yuko, O.; Shigeru, I.; Ayumi, T.; Yoshitaka, K. Environmental and Individual Correlates of Various Types of Physical Activity among Community-Dwelling Middle-Aged and Elderly Japanese. Int. J. Environ. Res. Public Health 2013, 10, 2028-2042.

31. Soltero, E.G.; Hernandez, D.C.; O'Connor, D.P.; Lee, R.E. Does Social Support Mediate the Relationship Among Neighborhood Disadvantage, Incivilities, Crime and Physical Activity. Prev. Med. 2015, 72, 44-49. [CrossRef] [PubMed] 
32. Lindrström, M. Social capital, desire to increase physical activity and leisure-time physical activity: A population-Based study. Public Health 2011, 125, 442-447. [CrossRef] [PubMed]

33. Pearce, J.R.; Maddison, R. Do enhancements to the urban built environment improve physical activity levels among socially disadvantaged populations? Int. J. Equity Health 2011, 10, 1-9. [CrossRef] [PubMed]

34. Singh, G.K.; Kogan, M.D.; Siahpush, M.; van Dyck, P.C. Independent and Joint Effects of Socioeconomic, Behavioral, and Neighborhood Characteristics on Physical Inactivity and Activity Levels Among US Children and Adolescents. J. Community Health 2008, 33, 206-216. [CrossRef] [PubMed]

35. Central Statistical Office. Beneficiaries of Social Assistance and Family Benefits in 2014; The Statistical Office: Krakow, Poland, 2015.

36. Assessment of Health Needs of the Residents of Piotrkowski District 2014. Available online: http:/ / www.zdrowie.powiatpiotrkowskipl/download/Download/Ocena_potrzeb_zdrowotnych_ powiat_piotrkowski.pdf (accessed on 5 October 2016).

37. United Nations Development Programme, National Human Development Report. Regional and Local Development. Available online: http://issuu.com/undp_poland/docs/lhdi_report_poland_2012_eng (accessed on 23 October 2016).

38. World Health Organization. Social Inequalities in Health in Poland; European Office of the World Health Organization: Warszawa, Poland, 2012.

39. Kaleta, D.; Wojtysiak, P.; Polańska, K. Use of electronic cigarettes among secondary and high school students from a socially disadvantaged rural area in Poland. BMC Public Health 2016, 15, 703. [CrossRef] [PubMed]

40. Drygas, W.; Niklas, A.A.; Piwońska, A.; Piotrowski, W.; Flotyńska, A.; Kwaśniewska, M.; Nadrowski, P.; Puch-Walczak, A.; Szafraniec, K.; Bielecki, W.; et al. Multi-centre National Population Health Examination Survey (WOBASZ II study): Assumptions, methods, and implementation. Kardiol. Pol. 2016, 74, 681-690. [CrossRef] [PubMed]

41. Drygas, W.; Kwaśniewska, M.; Kaleta, D.; Pikala, M.; Bielecki, W.; Głuszek, J.; Zdrojewski, T.; Pajak, A.; Kozakiewicz, K.; Broda, G. Epidemiology of physical inactivity in Poland: Prevalence and determinants in a former communist country in socioeconomic transition. Public Health 2009, 123, 592-597. [CrossRef] [PubMed]

42. Harkins, C.; Shaw, R.; Gillies, M.; Sloan, H.; Macintyre, K.; Scoular, A.; Morrison, C.; Mackay, F.; Cunningham, H.; Docherty, P.; et al. Overcoming barriers to engaging socio-economically disadvantaged populations in CHD primary prevention: A qualitative study. BMC Public Health 2010, 2, 391. [CrossRef] [PubMed]

43. Laverty, A.A.; Palladino, R.; Lee, J.T.; Millett, C. Associations between active travel and weight, blood pressure and diabetes in six middle income countries: A cross-sectional study in older adults. Int. J. Behav. Nutr. Phys. Act. 2015, 20, 65. [CrossRef] [PubMed]

44. Chen, Y.-J.; Huang, Y.-H.; Lu, F.-H.; Wu, J.-S.; Lin, L.L.; Chang, C.-J.; Yang, Y.-C. The Correlates of Leisure Time Physical Activity among an Adults Population from Southern Taiwan. BMC Public Health 2011, 11, 427. [CrossRef] [PubMed]

45. Azagba, S.; Sharaf, M.F. Physical inactivity among older Canadian adults. Phys. Act. Health 2014, 11, 99-108. [CrossRef] [PubMed]

46. O'Mara-Eves, A.; Bruton, G.; Oliver, S.; Kavanagh, J.; Jamal, F.; Thomas, J. The effectiveness of community engagement in public health interventions for disadvantaged groups: A meta-analysis. BMC Public Health 2015, 15, 129. [CrossRef] [PubMed]

47. Khan, K.M.; Thompson, A.M.; Blair, S.N.; Sallis, J.F.; Powell, K.E.; Bull, F.C.; Bauman, A.E. Sport and exercise as contributors to the health of nations. Lancet 2012, 380, 59-64. [CrossRef]

48. Lee, I.M.; Paffenberger, R.S. Associations of light, moderate, and vigorous physical activity with longevity. The Harvard Alumni Health Study. Am. J. Epidemiol. 2000, 151, 293-299. [CrossRef] [PubMed]

49. Department of Health and Human Services. Physical Activity Guidelines for Americans. 2008. Available online: www.health.gov / paguidelines/guidelines/default.aspx (accessed on 24 September 2017). 
50. Warburton, D.E.; Charlesworth, S.; Ivey, A.; Nettlefold, L.; Bredin, S.D. A systematic review of the evidence for Canada's Physical Activity Guidelines for Adults. Int. J. Behav. Nutr. Phys. Act. 2010, 7, 39. [CrossRef] [PubMed]

51. O'Donovan, G.; Blazevich, A.J.; Boreham, C.; Cooper, A.R.; Crank, H.; Ekelund, U.; Fox, K.R.; Gately, P.; Giles-Corti, B.; Gill, J.M.R.; et al. The ABC of physical activity for health: A consensus statement from the British Association of Sport and Exercise Sciences. J. Sports Sci. 2010, 28, 573-591. [CrossRef] [PubMed]

(C) 2017 by the authors. Licensee MDPI, Basel, Switzerland. This article is an open access article distributed under the terms and conditions of the Creative Commons Attribution (CC BY) license (http:/ / creativecommons.org/licenses/by/4.0/). 